\title{
Hasil Padi dan Kelimpahan Gulma dengan Aplikasi Jenis Pupuk Berbeda di Lahan Kering Tadah Hujan pada Musim Kemarau
}

\section{(Rice Yield and Weed Abundance with Application of Different Fertilizers in Rainfed Dryland during Dry Season)}

\author{
Yugi Rahayu Ahadiyat ${ }^{1^{*}}$, Sisno ${ }^{2}$ \\ (Diterima Juli 2020/Disetujui Maret 2021)
}

\begin{abstract}
ABSTRAK
Hasil padi dan pengendalian gulma yang tepat perlu ditingkatkan dengan pendekatan sistem pertanian ramah lingkungan di lahan tadah hujan selama musim kemarau melalui pengurangan dosis pupuk sintetik. Penelitian ini bertujuan mengevaluasi pengaruh aplikasi pupuk yang berbeda pada hasil padi dan kelimpahan gulma di lahan tadah hujan selama musim kemarau. Penelitian menggunakan Rancangan Petak Terbagi, dengan petak utama adalah varietas padi, yaitu varietas Situ Bagendit dan IR-64 dan anak petak adalah pupuk, yang terdiri atas pupuk sintetik $(\mathrm{N}, \mathrm{P}, \mathrm{K})$, pupuk organik $+\mathrm{P} 60+1 / 2$ dosis pupuk sintetik, pupuk organik + PGPR $+1 / 2$ dosis pupuk sintetik, dan pupuk organik + P60 + plant growth promoting rhizobacteria $(P G P R)+1 / 2$ dosis pupuk sintetik dengan tiga ulangan. Variabel yang diamati adalah komponen hasil padi, yaitu panjang malai, jumlah gabah hampa dan isi per malai, bobot gabah pada setiap rumpun, petak efektif dan per hektar, bobot 1000 gabah, dan indeks panen, dan summed dominance ratio gulma. Pemberian pupuk sintetik dan tiga ragam pupuk organik, pupuk hayati, dan pupuk sintetik memberikan hasil (SDR) yang beragam pada nilai SDR gulma. Gulma Sphenoclea zeynalica dan Cyperus difformis menunjukkan dominansi yang konsisten dengan SDR lebih tinggi dibandingkan gulma lainnya, yaitu masing-masing $>15$ dan $>10$. Aplikasi pupuk organik dan pupuk hayati dengan setengah dosis pupuk sintetik rekomendasi $\left(50 \mathrm{~kg} \mathrm{~N}, 50 \mathrm{~kg} \mathrm{P} \mathrm{P}_{2} \mathrm{O}_{5}\right.$, $25 \mathrm{~kg} \mathrm{~K}_{2} \mathrm{O}$ ) setara dengan aplikasi pupuk sintetik dosis rekomendasi pada musim kemarau dengan intensitas curah hujan rendah di lahan kering tadah hujan dengan hasil biji rendah sekitar 1,3-1,7 t/ha.
\end{abstract}

Kata kunci: gulma, hasil padi, pupuk hayati, pupuk organik, pupuk sintetik

\section{ABSTRACT}

Rice yield and proper weed control need to be increased through an environmentally friendly agricultural system approach in rainfed land during the dry season by reducing the dosage of synthetic fertilizers. This study aims to determine the effect of different fertilizer applications on rice yield and weed abundance in rainfed land during the dry season. The study used a split-plot design, with the main plot of rice variety, i.e., Situ Bagendit and IR-64, and subplots of fertilizer, namely synthetic fertilizers $(N, P, K)$, organic fertilizers $+P 60+1 / 2$ dose of synthetic fertilizers, organic fertilizers + PGPR + $1 / 2$ dose of synthetic fertilizer and organic fertilizer + P60 + PGPR + 1/2 dose of synthetic fertilizer with three replications. The variables observed were rice yield components, namely panicle length, total empty grain and content per panicle, grain weights per hill, effective plot and hectare, 1000 grain weight, harvest index, and weeds summed dominance ratio (SDR). The synthetic fertilizers and three various organic fertilizers, biological fertilizers, and synthetic fertilizers gave different results on the SDR of weeds. The weeds of Sphenoclea zeynalica and Cyperus difformis showed consistent dominance with higher SDR than other weeds, i.e.,> 15 and $>10$, respectively. The application of organic and biological fertilizers with half the recommended dosage of the synthetic fertilizers is equivalent to applying the recommended dosage of synthetic fertilizers on rice yield during the dry season on the rainfed dryland with low rainfall intensity and a low yield of 1.3-1.7 t/ha.

Keywords: biological fertilizer, inorganic fertilizer, organic fertilizers, rice, weeds

\section{PENDAHULUAN}

Kebutuhan pangan semakin meningkat seiring dengan meningkatnya jumlah penduduk. Oleh karena itu, produksi pertanian khususnya padi sebagai sumber

${ }^{1}$ Laboatorium Agroekologi, Program Studi Agroteknologi, Fakultas Pertanian, Universitas Jenderal Soedirman, Jl. Dr. Soeparno Karangwangkal Purrwokerto 53123

2 Laboatorium IImu Tanah, Program Studi Agroteknologi, Fakultas Pertanian, Universitas Jenderal Soedirman, J. Dr. Soeparno Karangwangkal Purrwokerto 53123

* Penulis Korespondensi: Email: ahadiyat_yugi@yahoo.com karbohidrat yang merupakan makanan pokok nasional harus ditingkatkan, supaya kebutuhan pangan masyarakat dapat terpenuhi. Keseimbangan antara permintaan dan produksi padi perlu dipertahankan sehingga setiap negara penghasil padi berusaha mempertahankan bahkan meningkatkan produktivitasnya.

Solusi untuk memenuhi kebutuhan tersebut di antaranya adalah dengan memperbaiki sistem budi daya padi melalui pemupukan yang tepat. Namun, pemupukan dengan pupuk sintetik dalam budi daya padi tidak selalu sesuai dengan dosis rekomendasi dan 
berdampak buruk pada lingkungan (Triyono et al. 2013). Oleh karena itu, penggunaan pupuk sintetik yang berlebihan yang menyebabkan terjadinya degradasi tanah perlu ditekan melalui aplikasi pupuk organik (Sennang et al. 2012). Pupuk organik berperan dalam mendukung pertumbuhan tanaman antara lain pada jagung (Madauna, 2009), padi (Supartha et al. 2012), dan kedelai (Hanum 2013).

Selain aplikasi pupuk organik, penggunaan pupuk hayati pun sudah banyak dikaji dan mampu memperbaiki kualitas dan kuantitas hasil tanaman. Beberapa penelitian sudah mengkaji pengaruhnya pada tanaman padi antara lain Azotobacter sp. (Sennang et al. 2012; Aryanto et al. 2015), Pseudomonas fluorescens (Navitasari et al. 2013), Bacillus sp. dan Azospirillum sp. (Aryanto et al. 2015).

Pseudomonas fluorescens (P60) merupakan salah satu bakteri antagonis yang banyak dimanfaatkan pada sebagai pupuk hayati untuk mengendalikan beberapa jamur dan bakteri patogen tanaman (Nasrun \& Nurmansyah 2016), bahkan bisa menghasilkan auksin (Khakipour et al. 2008), meningkatkan pertumbuhan (Anhar et al. 2011) dan kualitas bibit (Navitasari et al. 2013), dan menjaga viabilitas benih (Krisnandika et al. 2017). Bakteri lain yang dapat dimanfaatkan mendukung produksi tanaman adalah plant growth promoting rizhobacteria (PGPR), yang mampu memacu pertumbuhan tanaman (Ahemad and Kibret, 2014) antara lain pada cabai (Taufik 2010), bawang merah (Kafrawi et al. 2015), pepaya (Nasib et al. 2016), tebu (Sulistyoningtyas et al. 2017), kacang tanah (Marom et al. 2017), padi (Nafiah \& Suryanto 2018), dan kedelai (Utami et al. 2018). Hal ini membuktikan bahwa PGPR bermanfaat positif pada berbagai tanaman pangan, sayuran, dan tanaman tahunan.

Permasalahan lain yang sering ditemukan di lapangan dan sangat memengaruhi produksi dan produktivitas tanaman adalah gulma. Gulma mampu tumbuh dan berkembang pada semua jenis tanah dan pada lahan optimal maupun marginal. Hasil menurun akibat gulma karena tanaman berkompetisi dalam memanfaatan sumber daya di lingkungan tumbuh yang sama (Rakian et al. 2018). Penurunan hasil padi secara nasional akibat gangguan gulma berkisar dari 6 sampai $87 \%$ (Utami \& Purdyaningrum 2012), bergantung pada sistem pengendalian yang diterapkan.

Aplikasi pupuk organik cenderung meningkatkan kelimpahan gulma (Hutapea et al. 2015) dan menurut Suryadiyansyah (2017), aplikasi pupuk hayati mampu meningkatkan hasil padi tetapi belum mampu menekan pertumbuhan gulma. Hal ini menunjukkan perlunya formulasi yang tepat dalam pemberian pupuk organik dan pupuk hayati agar tidak menimbulkan dampak negatif pada tanaman padi akibat kelimpahan gulma yang tinggi.

Berdasarkan potensi pupuk organik dan pupuk hayati terhadap produksi tanaman dan dampaknya pada keberadaan gulma, maka dalam penelitian ini dikombinasikan antara pupuk organik dan pupuk hayati. Dosis pupuk sintetik dikurangi dalam rangka mendapatkan formula pemupukan yang tepat dalam mendukung hasil padi dan efektivitasnya dalam menekan pertumbuhan gulma. Tujuan penelitian ini adalah mengevaluasi kelimpahan gulma dan hasil padi yang diberi kombinasi pupuk sintetik, pupuk organik, dan pupuk hayati. Dari hasil penelitian ini diharapkan dapat diperoleh sistem budi daya padi yang lebih ramah lingkungan dengan aplikasi pupuk sintetik dosis rendah.

\section{METODE PENELITIAN}

Penelitian dilaksanakan di lahan kering tadah hujan di Desa Banjarsari, Kecamatan Sumbang, Kabupaten Banyumas, pada ketinggian tempat $165 \mathrm{~m}$ di atas permukaan laut, mulai Juli sampai Oktober 2012 pada musim kemarau dengan karakter cuaca rata-rata bulanan antara lain intensitas curah hujan, suhu, dan kelembapan masing-masing $87,00 \mathrm{~mm}, 31,63^{\circ} \mathrm{C}$, dan $61,75 \%$ (Gambar 1), serta jenis tanah inseptisol yang menunjukan karakter kesuburan tanah sedang (Soil Survey Staff 2014).

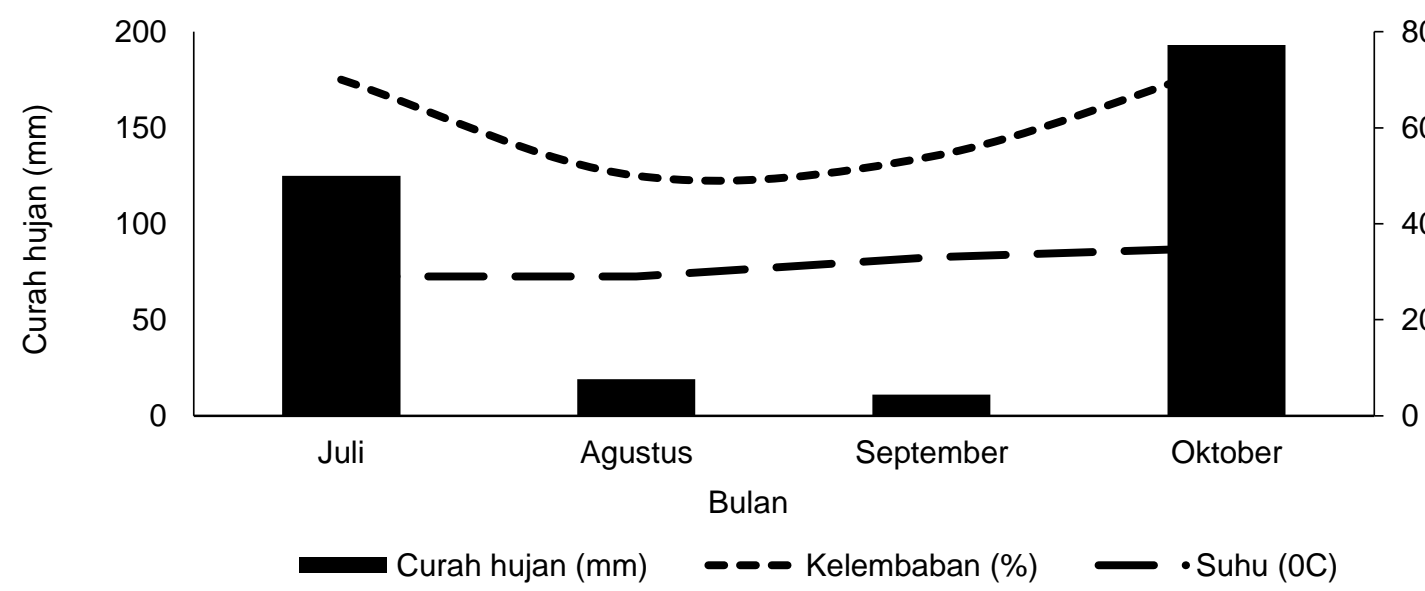


Bahan utama yang digunakan ialah dua varietas padi, Situ Bagendit dan IR-64. Pupuk yang digunakan antara lain pupuk organik, yaitu pupuk organik (kotoran sapi), serta pupuk sintetik [urea (N), SP-36 (P), KCl (K)]. Pupuk hayati yang digunakan ialah plant growth promoting rizhobacteria (PGPR) dan Pseudomonas fluorescens P60.

Eksperimen ini menggunakan Rancangan Petak Terbagi (Split Plot Design). Faktor yang dicoba ialah petak utama berupa varietas padi, yaitu Situ Bagendit dan IR-64, dan anak petak, yaitu pupuk yang terdiri atas pupuk sintetik $(N, P, K)$, pupuk organik $+P 60+1 / 2$ dosis pupuk sintetik, pupuk organik + PGPR $+1 / 2$ dosis pupuk sintetik, dan pupuk organik + P60 + PGPR + 1/2 dosis pupuk sintetik. Setiap perlakuan diulang tiga kali sehingga keseluruhan berjumlah 24 petak percobaan.

Ukuran petak yang digunakan adalah $2 \mathrm{~m} \times 4 \mathrm{~m}$ di atas lahan kering yang berada pada wilayah tadah hujan. Benih ditanam secara tugal dengan isi 3 benih per lubang, jarak tanam $25 \mathrm{~cm} \times 25 \mathrm{~cm}$, dan kemudian dipilih 2 yang terbaik saat tanaman berumur 14 hari setelah tanam (hst).

Dosis yang digunakan untuk aplikasi pupuk organik adalah $10 \mathrm{t} / \mathrm{ha}$, diaplikasikan 2 pekan sebelum tanam saat pengolahan lahan. Pupuk sintetik $(100 \mathrm{~kg} \mathrm{~N}, 100$ $\mathrm{kg} \mathrm{P}_{2} \mathrm{O}_{5}, 50 \mathrm{~kg} \mathrm{~K}_{2} \mathrm{O}$ ) diaplikasikan berdasarkan rekomendasi dari Dinas Pertanian Provinsi Jawa Tengah. Pupuk $\mathrm{P}$ dan $\mathrm{K}$ diaplikasikan saat tanaman berumur 14 hari sesuai dengan dosis, dan pupuk $\mathrm{N}$ diaplikasikan 2 kali, yaitu saat tanaman berumur 14 dan 35 hari. Pupuk sintetik diaplikasikan secara tugal di sekitar perakaran tanaman. P60 disemprotkan ke bagian tajuk tanaman menggunakan handsack sprayer dengan interval 2 minggu menggunakan dosis $20 \mathrm{~mL}$ per rumpun pada aplikasi umur 2-6 minggu setelah tanam (mst) dan $40 \mathrm{~mL}$ per rumpun pada aplikasi umur 8-10 mst. PGPR diaplikasikan pada umur 2 mst, saat menjelang berbunga ( $9 \mathrm{mst}$ ) dan saat pengisian biji (12 mst).

Parameter yang diamati meliputi kerapatan relatif $(\mathrm{KR})$, frekuensi relatif (FR), dan dominansi relatif (DR) untuk mendapatkan nilai summed dominance ratio $(S D R)$ dari gulma yang ada di areal tanam (Madauna 2009).

$$
\begin{gathered}
\text { Kerapatan Relatif }=\frac{\text { Kerapatan suatu spesies }}{\text { Kerapatan total semua spesies }} \times 100 \% \\
\text { Frekuensi Relatif }=\frac{\text { Frekuensi suatu spesies }}{\text { Frekuensi total semua spesies }} \times 100 \% \\
\text { Dominansi Relatif }= \\
\text { Nilai penting }=\begin{array}{c}
\text { Dominansinansi total semua spesies } \\
\text { kerapan relatif }+ \text { frekuensi relatif } \\
+ \text { dominansi relatif }
\end{array} \\
\text { Summed Dominace Ratio }(S D R)=\frac{\text { Nilai Penting }}{3}
\end{gathered}
$$

Pertumbuhan gulma pada lahan penelitian diamati 2 kali saat penutupan tajuk tanaman padi terhadap area tanam masih rendah, yaitu pengamatan I saat tanaman padi berumur $28 \mathrm{hst}$, dan pengamatan II saat tanaman padi berumur 49 hst. Gulma diamati dengan metode sampling secara diagonal di 5 titik dengan ukuran setiap titik sampling $50 \mathrm{~cm} \times 50 \mathrm{~cm}$ pada setiap petak percobaan. Sampel gulma yang didapat kemudian diidentifikasi jenisnya dan dihitung nilai kerapatan, frekuensi, dan dominansinya untuk mendapatkan nilai SDR.

Komponen hasil meliputi panjang malai, jumlah gabah hampa dan isi per malai, bobot gabah per rumpun dan per petak efektif dan per hektare, bobot 1000 gabah, dan indeks panen diamati saat panen. Sampel untuk komponen hasil berasal dari 10 sampel rumpun per perlakuan yang diambi dari petak efektif selain baris pinggir. Untuk data hasil biji per petak efektif, per hektare, dan indeks panen diambil dari hasil biji dalam petak efektif setiap perlakuan dengan mengabaikan baris padi pinggir atau terluar.

Data pengamatan komponen hasil yang diperoleh dianalisis dengan menggunakan uji $F$ pada taraf $p=$ 0,05 . Apabila terdapat pengaruh nyata pada variabel yang diamati, uji dilanjutkan dengan uji Beda Nyata Jujur (BNJ) pada taraf $p=0,05$ untuk menilai pengaruh setiap perlakuan yang dicoba.

\section{HASIL DAN PEMBAHASAN}

\section{Pengaruh aplikasi pupuk organik, sintetik, dan pupuk hayati pada SDR Gulma}

Nilai SDR yang menunjukkan gulma dominan pada saat tanaman padi berumur 28 hari setelah tanam (hst) (pengamatan I) ialah Sphenoclea zeynalica (SDR >30), Cyperus difformis (SDR >15), Echinochloa crusgalli (SDR >8), dan Ludwigia adscendens (SDR >5) (Tabel 1). Keempat jenis gulma tersebut memiliki tingkat dominansi yang leibh tinggi dibandingkan gulma lainnya.

Pada pengamatan I (28 hst), berdasarkan dominansi gulma, antar-varietas dengan aplikasi pemupukan yang berbeda menunjukkan kelimpahan yang beragam. Gulma $S$. zeynalica yang tumbuh di area pertanaman varietas Situ Bagendit dengan aplikasi pupuk sintetik $(\mathrm{N}, \mathrm{P}, \mathrm{K})$ menunjukkan nilai SDR $<30$, lebih rendah dibandingkan dengan aplikasi pupuk organik dan pupuk hayati dengan $1 / 2$ dosis pupuk sintetik, tetapi sebaliknya pada area pertanaman varietas IR-64 menghasikan SDR >30 (Tabel 1).

Dominansi gulma $C$. difformis memperlihatkan hal yang hampir sama, SDR $>15$, dengan aplikasi pupuk sintetik dibandingkan dengan aplikasi pupuk organik dan pupuk hayati dengan $1 / 2$ dosis pupuk sintetik pada petak yang ditanami kedua varietas tersebut. Kelimpahan gulma tinggi ditunjukkan oleh E. crusgalli (SDR >10) pada petak yang ditanami varietas Situ Bagendit, tetapi kelimpahannya rendah saat berada pada petak yang ditanami padi varietas IR-64 dengan SDR $<8$. Nilai SDR $L$. adscendens pada petak yang ditanami padi varietas Situ Bagendit dan IR-64 menghasilkan kisaran nilai yang hampir sama dengan 
Tabel 1 Summed Dominance Ratio (SDR) gulma Pengamatan I saat tanaman padi berumur 28 hst di lahan kering tadah hujan pada musim kemarau

\begin{tabular}{|c|c|c|c|c|c|c|c|c|c|}
\hline \multirow{3}{*}{ Jenis } & \multirow{3}{*}{ Spesies } & \multicolumn{8}{|c|}{ SDR } \\
\hline & & \multicolumn{4}{|c|}{ V1 } & \multicolumn{4}{|c|}{ V2 } \\
\hline & & $\mathrm{P} 1$ & P2 & P3 & P4 & $\mathrm{P} 1$ & P2 & P3 & P4 \\
\hline DL & $\begin{array}{l}\text { Sphenoclea zeynalica } \\
\text { Gaertn. }\end{array}$ & 23,46 & 43,08 & 30,59 & 37,73 & 31,43 & 24,79 & 27,84 & 31,21 \\
\hline $\mathrm{DL}$ & $\begin{array}{l}\text { Monochoria vaginalis } \\
\text { (Burm.f) Presl }\end{array}$ & 17,71 & 13,28 & 20,01 & 13,60 & 14,85 & 22,85 & 20,70 & 25,09 \\
\hline $\mathrm{DL}$ & $\begin{array}{l}\text { Ludwigia hyssopifolia (G. } \\
\text { Don) Exell }\end{array}$ & - & 1,70 & 2,01 & - & - & - & - & - \\
\hline DL & $\begin{array}{l}\text { Lindernia antipoda (L.) } \\
\text { Alston }\end{array}$ & 1,92 & 9,58 & 4,76 & 8,30 & 1,45 & 1,62 & 3,53 & 1,81 \\
\hline $\mathrm{DL}$ & $\begin{array}{l}\text { Ludwigia adscendens (L.) } \\
\text { Hara }\end{array}$ & 6,30 & 7,86 & 5,92 & 5,52 & 6,17 & 6,95 & 5,19 & 6,90 \\
\hline $\mathrm{DL}$ & $\begin{array}{l}\text { Phylantus niruri - see } \\
\text { P.fraternus }\end{array}$ & - & - & - & 1,53 & - & - & - & - \\
\hline DL & $\begin{array}{l}\text { Synedrella nodiflora (L.) } \\
\text { Gaertn. }\end{array}$ & 1,55 & 2,21 & 1,79 & 5,15 & 2,89 & 1,59 & 2,37 & - \\
\hline $\mathrm{DL}$ & $\begin{array}{l}\text { Alternanthera philoxeoides } \\
\text { (Mart.) Griseb }\end{array}$ & - & - & - & 1,48 & 1,33 & 0,11 & - & - \\
\hline $\mathrm{DL}$ & $\begin{array}{l}\text { Marsilea crenata - see M. } \\
\text { Minuta }\end{array}$ & - & - & - & - & 0,34 & - & - & - \\
\hline TT & Cyperus difformis L. & 18,76 & 4,58 & 7,95 & 8,60 & 17,47 & 17,10 & 12,40 & 10,91 \\
\hline TT & Cyperus compressus L. & 8,63 & - & 3,85 & 3,17 & 4,47 & 6,38 & 10,39 & 5,65 \\
\hline TT & $\begin{array}{l}\text { Fimbristyllis miliacea (L.) } \\
\text { Vahl }\end{array}$ & 4,88 & 7,70 & 8,24 & 4,27 & 5,50 & 5,30 & 6,09 & 2,05 \\
\hline $\mathrm{RR}$ & Panicum repens L. & 5,93 & 6,05 & 5,18 & 8,45 & 6,11 & 3,92 & 2,22 & 3,97 \\
\hline RR & $\begin{array}{l}\text { Echinochloa crusgalli (L.) } \\
\text { P. Beauv }\end{array}$ & 10,87 & 3,97 & 9,71 & 2,21 & 8,00 & 9,38 & 9,29 & 12,41 \\
\hline & Total & 100 & 100 & 100 & 100 & 100 & 100 & 100 & 100 \\
\hline
\end{tabular}

Keterangan: DL: Daun lebar, TT: Teki, RR: Rumput, V1: Situ Bagendit, V2: IR-64, P1: Pupuk sintetik, P2: Pupuk organik + P60 + 1/2 dosis pupuk sintetik, P3: Pupuk organik + PGPR + 1/2 dosis pupuk sintetik, P4: Pupuk organik + P60 + PGPR + $1 / 2$ dosis pupuk sintetik, hst: hari setelah tanam; dan SDR: summed dominance ratio.

SDR, yakni antara 5 dan 6 dengan perlakuan pemupukan yang berbeda (Tabel 1 ).

Terdapat perubahan dominansi gulma saat tanaman padi berumur 49 hst. Secara umum, dominansi tinggi diperlihatkan oleh S. zeynalica (SDR 18-20), Monochoria vaginalis (SDR $>15)$, C. difformis (SDR >10), Fimbristylis miliacea (SDR 8-12), dan Lindernia antipoda (>10) (Tabel 2). Pengamatan pada umur 49 hst menunjukkan pergeseran dominansi gulma dan penurunan nilai SDR dibandingkan saat tanaman padi berumur 28 hst. Namun, gulma $S$. zeynalica dan $C$. difformis masih dominan dibandingkan dengan gulma yang lain (Tabel 2).

Kelimpahan S. zeynalica pada umur padi 49 hst antarvarietas dengan pola pemupukan yang berbeda menggambarkan hasil yang hampir sama, yaitu kisaran SDR 18-20. Kelimpahan yang sama ditampilkan oleh gulma $F$. miliacea dengan SDR 8-12. Aplikasi pupuk sintetik pada kedua varietas memberikan respons berbeda pada kelimpahan gulma $M$. vaginalis, dengan hasil SDR $<15$ pada petak yang ditanami padi varietas Situ Bagendit dan SDR $>15$ pada petak varietas IR-64 (Tabel 2).

Pola kelimpahan gulma $C$. difformis dan $L$. antipoda berbeda pada petak varietas padi dengan aplikasi pupuk berbeda. Kelimpahan $C$. difformis tinggi dengan nilai SDR $>15$ saat petak padi varietas Situ Bagendit diberi pupuk sintetik dan berkebalikan dengan petak yang ditanami padi varietas IR-64 dengan nilai SDR $<10$ (Tabel 2).

Secara umum, terjadi pergeseran dominansi beberapa gulma di saat umur tanaman padi bertambah. (Hutapea et al. 2015) menyatakan bahwa dominansi gulma akan bergeser karena gulma yang tumbuh dalam durasi waktu tertentu tidak hanya berasal dari infestasi di lahan asal tetapi berasal dari invasi gulma dari luar. Bagaimanapun, beberapa gulma antara lain C. difformis, S. zeynalica, dan $M$. vaginalis tetap dominan meskipun dengan tingkat dominansi yang berbeda dibandingkan dengan sebelumnya. Hal yang sama dilaporkan oleh Toure et al. (2013), bahwa beberapa gulma memperlihatkan dominansi yang sama pada pengamatan di tahun berbeda meskipun dengan tingkat dominansi berbeda.

Aplikasi pupuk sintetik pada petakan varietas padi yang berbeda pun mengindikasikan pola yang berbeda dalam hal kelimpahan gulma. Aplikasi pupuk sintetik cenderung meningkatkan kelimpahan gulma yang tinggi walaupun ada juga yang lebih rendah dibandingkan dengan aplikasi pupuk organik dan pupuk hayati dengan pemberian pupuk N,P,K $1 / 2$ dosis rekomendasi. Keberadaan nutrisi dalam tanah cenderung memberikan respons yang berbeda pada pertumbuhan dan dominansi gulma. Total individu yang tinggi akan menghasilkan bobot kering biomasa yang tinggi. Kelimpahan gulma dengan SDR lebih 
Tabel 2 Summed Dominance Ratio (SDR) gulma Pengamatan II saat tanaman padi berumur 49 hst di lahan kering tadah hujan pada musim kemarau

\begin{tabular}{|c|c|c|c|c|c|c|c|c|c|}
\hline \multirow{3}{*}{ Jenis } & \multirow{3}{*}{ Spesies } & \multicolumn{8}{|c|}{ SDR } \\
\hline & & \multicolumn{4}{|c|}{ V1 } & \multicolumn{4}{|c|}{ V2 } \\
\hline & & $\mathrm{P} 1$ & $\mathrm{P} 2$ & P3 & P4 & $\mathrm{P} 1$ & $\mathrm{P} 2$ & P3 & $\mathrm{P} 4$ \\
\hline $\mathrm{DL}$ & $\begin{array}{l}\text { Sphenoclea zeynalica } \\
\text { Gaertn. }\end{array}$ & 18,05 & 20,13 & 18,58 & 23,96 & 19,79 & 18,44 & 20,41 & 20,37 \\
\hline $\mathrm{DL}$ & $\begin{array}{l}\text { Monochoria vaginalis } \\
\text { (Burm.f) Presl }\end{array}$ & 9,95 & 16,25 & 17,39 & 10,72 & 15,56 & 12,99 & 9,43 & 18,43 \\
\hline $\mathrm{DL}$ & Ammannia baccifera $\mathrm{L}$. & 5,35 & 5,23 & 1,63 & 5,62 & 2,60 & 3,04 & 5,79 & 5,87 \\
\hline DL & $\begin{array}{l}\text { Ludwigia hyssopifolia } \\
\text { (G. Don) Exell }\end{array}$ & 4,26 & 5,81 & 6,59 & 5,22 & 4,82 & 5,89 & 6,04 & 7,03 \\
\hline DL & $\begin{array}{l}\text { Lindernia antipoda (L.) } \\
\text { Alston }\end{array}$ & 8,42 & 14,37 & 13,92 & 16,85 & 9,90 & 12,13 & 10,45 & 13,78 \\
\hline $\mathrm{DL}$ & $\begin{array}{l}\text { Lindernia procumbens } \\
\text { (Krock.) Phicox }\end{array}$ & 11,14 & 11,45 & 11,69 & 7,61 & 10,49 & 14,32 & 9,61 & 10,37 \\
\hline $\mathrm{DL}$ & $\begin{array}{l}\text { Hydrolea zeylanica (L.) } \\
\text { Vahl } \\
\text { Alternanthera }\end{array}$ & 3,29 & 1,30 & - & 1,75 & 3,86 & 1,78 & 1,60 & - \\
\hline DL & $\begin{array}{l}\text { philoxeoides (Mart.) } \\
\text { Griseb }\end{array}$ & 1,51 & - & 1,63 & 1,80 & 2,90 & 2,03 & - & - \\
\hline TT & $\begin{array}{l}\text { Fimbristylis dichotoma } \\
\text { (L.) Vahl }\end{array}$ & - & 6,05 & 4,04 & 2,04 & - & 2,22 & 1,27 & - \\
\hline TT & $\begin{array}{l}\text { Fimbristylis miliacea (L.) } \\
\text { Vahl }\end{array}$ & 7,01 & 6,66 & 5,98 & 7,99 & 11,82 & 8,72 & 11,97 & 11,95 \\
\hline TT & Cyperus difformis L. & 16,34 & 7,07 & 11,09 & 9,41 & 6,60 & 9,93 & 12,09 & 9,77 \\
\hline TT & Cyperus compressus L. & 3,06 & 1,66 & 2,72 & - & 4,83 & 3,13 & 1,41 & - \\
\hline TT & Cyperus rotundus L. & - & - & - & 1,51 & - & - & 3,84 & - \\
\hline $\mathrm{RR}$ & $\begin{array}{l}\text { Leptochloa chinensis } \\
\text { (L.) Nees }\end{array}$ & 2,15 & 1,54 & 1,30 & - & 1,58 & - & 2,13 & 2,43 \\
\hline $\mathrm{RR}$ & $\begin{array}{l}\text { Eulisine indica (L.) } \\
\text { Gaertn }\end{array}$ & 3,31 & - & 1,87 & 3,38 & 2,30 & 2,78 & - & - \\
\hline $\mathrm{RR}$ & $\begin{array}{l}\text { Echinochloa crusgalli } \\
\text { (L.) P. Beauv }\end{array}$ & 6,16 & 2,47 & 1,56 & 2,15 & 2,94 & - & 1,68 & - \\
\hline $\mathrm{RR}$ & Panicum repens $\mathrm{L}$. & - & - & - & - & - & 2,59 & 2,28 & - \\
\hline Total & 100 & 100 & 100 & 100 & 100 & 100 & 100 & 100 & 100 \\
\hline
\end{tabular}

rendah akibat aplikasi pupuk sintetik dibandingkan dengan aplikasi pupuk organik atau pupuk hayati dilaporkan pula Utami \& Purdyaningrum (2012) dan Antralina et al. (2014). Hal ini mengisyaratkan perlunya seleksi yang cermat dalam penggunaan pupuk organik dan pupuk hayati sehingga tidak menimbulkan masalah dalam pengendalian gulma. Kelimpahan gulma dipengaruhi oleh varietas dan aplikasi pupuk berbeda pada umur tanaman padi berbeda. Hal ini dipengaruhi oleh keberadaan nutrisi dari pupuk yang diaplikasikan, juga oleh perbedaan genetik varietas tersebut dalam bersaing dengan gulma. Keragaman varietas padi menunjukkan karakter genetik yang berbeda sehingga kemampuannya bersaing dengan gulma dari alelopati internal yang dihasilkannya pun berbeda (Khanh et al. 2007; Chen et al. 2008; Seal \& Pratley 2010). Selanjutnya, Ma et al. (2014) juga menemukan bahwa varietas padi yang berbeda memiliki kemampuan dalam menghasilkan eksudat alelopati yang berbeda yang berpotensi menekan pertumbuhan gulma di sekitar tanaman. Selain faktor varietas, menurut Rahnavard et al. (2009) dan Tang et al. (2014), aplikasi pupuk memengaruhi keberadaan gulma di lingkungan pertanaman, karena kompetisi antara tanaman dan gulma dalam memanfaatkan nutrisi memengaruhi komposisi dan keragaman gulma yang tumbuh.

\section{Pengaruh aplikasi pupuk organik, sintetik, dan pupuk hayati pada hasil padi}

Perbedaan varietas padi dan perlakuan pemupukan menunjukkan hasil yang tidak berbeda nyata pada semua variabel komponen hasil (Tabel 3). Pada penelitian ini, varietas Situbagendit dan IR-64 memiliki daya tanggap yang sama terhadap perlakuan pemupukan yang berbeda pada semua variabel komponen hasil.

Variabel panjang malai, jumlah gabah isi per malai, jumlah gabah hampa per malai, bobot gabah per petak efektif, bobot gabah per rumpun, bobot 1000 biji, dan indeks panen tidak berbeda nyata antara yang diberi pupuk organik dan pupuk hayati dengan setengah dosis pupuk sintetik rekomendasi jika dibandingkan dengan aplikasi pupuk sintetik dosis rekomendasi. Hal ini mengindikasikan bahwa pengurangan dosis pupuk sintetik sebanyak 50\% mampu menghasilkan karakter 
Tabel 3 Komponen hasil varietas padi yang diberi pupuk berbeda di lahan tadah hujan pada musim kemarau

\begin{tabular}{|c|c|c|c|c|c|c|c|}
\hline Perlakuan & $\begin{array}{l}\text { PM } \\
\text { (cm) }\end{array}$ & $\begin{array}{l}\text { JGIM } \\
\text { (butir) }\end{array}$ & $\begin{array}{l}\text { JGHM } \\
\text { (butir) }\end{array}$ & $\begin{array}{c}\text { BPE } \\
(\mathrm{g})\end{array}$ & $\begin{array}{c}\text { BGR } \\
(\mathrm{g})\end{array}$ & $\begin{array}{c}\text { BSB } \\
(\mathrm{g})\end{array}$ & IP \\
\hline \multicolumn{8}{|l|}{ Varietas (V) } \\
\hline V1 & $22,49 \mathrm{a}$ & 93,89 a & $27,64 \mathrm{a}$ & 797,07 a & $45,62 \mathrm{a}$ & $24,77 \mathrm{a}$ & $0,55 \mathrm{a}$ \\
\hline V2 & $22,14 \mathrm{a}$ & $104,24 \mathrm{a}$ & $26,99 \mathrm{a}$ & $819,35 \mathrm{a}$ & $48,04 \mathrm{a}$ & $25,56 \mathrm{a}$ & $0,54 \mathrm{a}$ \\
\hline$F_{0.05}(\mathrm{~V})$ & tn & tn & tn & tn & tn & tn & tn \\
\hline \multicolumn{8}{|c|}{ Pemupukan (P) } \\
\hline P1 & $22,37 \mathrm{a}$ & $94,28 \mathrm{a}$ & $29,64 \mathrm{a}$ & $858,80 a$ & $48,67 \mathrm{a}$ & $24,71 \mathrm{a}$ & $0,54 \mathrm{a}$ \\
\hline $\mathrm{P} 2$ & $22,31 \mathrm{a}$ & $98,75 \mathrm{a}$ & $28,94 \mathrm{a}$ & $741,30 \mathrm{a}$ & $48,52 \mathrm{a}$ & $25,14 a$ & $0,54 \mathrm{a}$ \\
\hline P3 & $22,46 \mathrm{a}$ & $102,45 a$ & $27,03 \mathrm{a}$ & $817,45 a$ & $43,10 a$ & $25,62 \mathrm{a}$ & $0,55 \mathrm{a}$ \\
\hline P4 & 22,12 a & $100,79 a$ & $23,65 \mathrm{a}$ & $815,28 \mathrm{a}$ & $47,03 \mathrm{a}$ & $25,18 \mathrm{a}$ & $0,55 \mathrm{a}$ \\
\hline $\mathrm{F}_{0.05}(\mathrm{P})$ & tn & tn & tn & tn & tn & tn & tn \\
\hline $\mathrm{F}_{0.05}(\mathrm{~V}, \mathrm{P})$ & tn & tn & tn & tn & tn & tn & tn \\
\hline
\end{tabular}

Keterangan: Angka yang diikuti dengan huruf yang sama berarti tidak berbeda nyata pada uji BNJ $(p=0,05)$. PM: panjang malai, JGIM: jumlah gabah isi per malai, JGHM: jumlah gabah hampa per malai, BPE: bobot gabah per petak efektif $\left(5,25 \mathrm{~m}^{2}\right)$, BGR: bobot gabah per rumpun, BSB: bobot 1000 Biji, IP: indeks panen, V1: Situ Bagendit, V2: IR 64, P1: pupuk sintetik, P2: pupuk organik + P60 + 1/2 dosis pupuk sintetik, P3: pupuk organik + PGPR + $1 / 2$ dosis pupuk sintetik, P4: pupuk organik + P60 + PGPR $+1 / 2$ dosis pupuk sintetik.

hasil yang setara apabila dikombinasikan dengan pupuk organik dan pupuk hayati. Aplikasi pupuk organik dengan pupuk sintetik dengan dosis tepat mampu menghasilkan karakter pertumbuhan yang optimum. Harjoso et al. (2011) memaparkan bahwa aplikasi pupuk kotoran sapi dan $50 \%$ pupuk sintetik pada padi varietas Situ Bagendit dan IR 64 berpotensi untuk dikembangkan karena mampu menghasilkan karakter pertumbuhan yang lebih baik dibandingkan dengan aplikasi $100 \%$ pupuk sintetik. Menurut Supartha et al. (2012), aplikasi pupuk organik berpotensi meningkatkan hasil padi meskipun belum menyamai aplikasi pupuk sintetik apabila dilakukan dalam satu musim tanam. Namun, kombinasi yang sesuai antara pupuk organik dan pupuk hayati dengan mengurangi dosis pupuk sintetik dapat menghasilkan produk yang optimum. Sennang et al. (2012) berpendapat bahwa aplikasi pupuk organik dan pupuk hayati memberikan pengaruh yang sama dalam hal komponen hasil padi dibandingkan dengan aplikasi pupuk anorganik.

Ketersediaan pupuk organik di tanah akan memperbaiki karakter tanah sehingga akan menjadi tempat yang ideal untuk mikroorganisme tumbuh dan berkembang. Oleh karena itu, aplikasi pupuk organik berperan dalam meningkatkan efisiensi penggunaan pupuk sintetik. Sebagaimana dikemukakan oleh Supriyo et al. (2014), aplikasi pupuk hayati dengan pupuk sintetik dosis $50 \%$ dosis rekomendasi mampu menghasilkan hasil padi yang setara dengan pupuk sintetik $100 \%$ dosis rekomendasi. Setiawati et al. (2016) menyimpulkan bahwa peningkatan dosis pupuk hayati yang diberikan mampu meningkatkan secara gradual serapan $\mathrm{N}$ dan $\mathrm{P}$ serta hasil padi. Hal ini diperkuat oleh Nafiah \& Suryanto (2018) bahwa aplikasi PGPR mampu menurunkan aplikasi pupuk $\mathrm{N}$ hingga lebih dari $50 \%$ dengan hasil yang setara dengan dosis optimumnya pada varietas padi Situ Bagendit. Hal yang sama diungkapkan oleh Gusmiatun
\& Marlina (2018) bahwa aplikasi pupuk organik dengan pupuk sintetik dosis $50 \%$ dosis rekomendasi mampu menghasilkan hasil padi setara dengan pupuk sintetik $100 \%$ dosis rekomendasi. Hal ini membuktikan peran penting pupuk organik dan pupuk hayati (PGPR dan P60) dalam upaya mengurangi penggunaan pupuk sintetik guna menghindari terjadinya pencemaran lingkungan di lingkungan pertanian. Bahkan pupuk organik dan pupuk hayati tersebut dapat diaplikasikan pada lahan marginal seperti yang diungkap oleh Aryanto et al. (2015), yakni bahwa pupuk hayati mampu meningkatkan efisiensi penggunaan pupuk sintetik $50 \%$ dari dosis rekomendasi di tanah masam.

Hasil biji yang diperoleh sangat rendah, kurang dari 2 t/ha, yaitu di bawah potensi hasil berdasarkan Deskripsi Varietas Unggul Padi untuk varietas Situ Bagendit dan IR 64 dengan rata-rata hasil 4-5 t/ha (Suprihatno et al. 2010). Hal ini karena saat tanaman memasuki fase pertumbuhan vegetatif linear dan berbunga kemudian dilanjutkan dengan fase pengisian biji, lahan berada dalam kondisi kekeringan karena intensitas curah hujan yang sangat rendah (Gambar 1). Tanaman mengalami cekaman kekeringan meskipun tidak menyebabkan kematian, tetapi berdampak pada perkembangan tanaman khususnya pembentukan biji. Oleh karena itu, aplikasi pupuk organik dan pupuk hayati belum mampu mempertahankan hasil saat terjadi kekeringan. Guimaraes et al. (2016) pun berpendapat bahwa tanaman padi yang mengalami cekaman kekeringan akan terganggu dalam proses fertilisasi dan proses pembentukan biji. Kombinasi pupuk organik dan pupuk hayati berpotensi menyamai aplikasi pupuk sintetik dalam hal hasil; oleh sebab itu, perlu dikembangkan penelitian pada kondisi yang lebih optimum tanpa ada cekaman kekeringan guna mendukung sistem budi daya tanaman khususnya padi yang lebih ramah lingkungan di lahan kering tadah hujan. 


\section{KESIMPULAN}

Gulma pada pertanaman padi yang diberi pupuk organik dan pupuk hayati dengan aplikasi pupuk anroganik setengah rekomendasi relatif memiliki SDR lebih tinggi dibandingkan dengan aplikasi pupuk sintetik rekomendasi. Namun, gulma $S$. zeynalica dan C. difformis menunjukkan dominansi yang konsisten, yaitu masing-masing $>15$ dan $>10$ dibandingkan dengan gulma lainnya dengan aplikasi pemupukan pada varietas yang berbeda.

Pemberian pupuk organik dan pupuk hayati pada varietas Situ Bagendit dan IR 64 di lahan kering tadah hujan pada musim kemarau mampu meningkatkan efisiensi pupuk sintetik $50 \%$ dengan hasil yang setara dibandingkan dengan aplikasi pupuk sintetik dosis rekomendasi meskipun dengan hasil yang rendah (1,3-1,7 t/ha) akibat intensitas curah hujan yang sangat rendah saat fase pembungaan dan pengisian biji.

\section{DAFTAR PUSTAKA}

Ahemad M, Kibret M. 2014. Mechanisms and applications of plant growth promoting rhizobacteria: Current perspective. Journal of King Saud University Science. 26(1): 1-20. https:// doi.org/10.1016/j.jksus.2013.05.001

Anhar A, Doni F, Advinda L. 2011. Respons pertumbuhan tanaman padi (oryza sativa L.) terhadap introduksi Pseudomonas fluoresen. Eksakta. 12(1): 1-11.

Antralina M, Yuwariah Y, Simarmata T. 2014. Komposisi gulma pada berbagai jarak tanam padi secara IPAT-BO dan konvensional. Jurnal Agro. 1(1): 14-21. https://doi.org/10.15575/77

Aryanto A, Triadiati, Sugiyanta. 2015. Pertumbuhan dan produksi padi sawah dan gogo dengan pemberian pupuk hayati berbasis bakteri pemacu tumbuh di tanah masam. Jurnal IImu Pertanian Indonesia. 20(3): 229-235. https://doi.org/ 10.18343/jipi.20.3.229

Chen XH, Hu F, Kong CH. 2008. Varietal improvement in rice allelopathy. Allelopathy Journal. 22(2): 379-384.

Guimarães CM, de Castro AP, Stone LF, de Oliveira JP. 2016. Drought tolerance in upland rice: identification of genotypes and agronomic characteristics. Acta Scientiarum. 38(2): 201-206. https://doi.org/10.4025/actasciagron.v38i2.27164

Gusmiatun, Marlina N. 2018. Peran pupuk organik dalam mengurangi pupuk sintetik pada budidaya padi gogo. Agrikan. 11(2): 91-99. https:// doi.org/10.29239/j.agrikan.11.2.91-98
Hanum C. 2013. Pertumbuhan, hasil, dan mutu biji kedelai dengan pemberian pupuk organik dan fosfor. Jurnal Agronomi Indonesia. 41(3): 209-214.

Harjoso T, Nurchasanah S, Ahadiyat YR. 2011. Karakter morfologi padi pada pertanaman dengan pendekatan SRI (System of Rice Intensification). Jurnal Agrin. 15(2): 153-163.

Hutapea C, Syofian M, Sudirman A. 2015. Pengaruh berbagai jenis pupuk organik terhadap spesies gulma invasif. Jurnal Agro Industri Perkebunan. 3(1): 21-33.

Kafrawi, Kumalawati Z, Muliani S. 2015. Skrining isolat Plant Growth Promoting Rhizobacteri (PGPR) dari pertanaman bawang merah (Allium ascalonicum) di Gorontalo, In: Prosiding Seminar Nasional Mikrobiologi Kesehatan dan Lingkungan. Jurusan Biologi, Fakultas Sains dan Teknologi, UIN Alauddin Makassar, Makassar, 29 Januari 2015. Makassar (ID).

Khakipour N, Khavazi K, Mojallali H, Pazira E, Asadirahmani H. 2008. Production of auxin hormone by Pseudomonads fluorescent. AmericanEurasian Journal of Agricultural and Environmental Sciences. 4(6): 687-692.

Khanh TD, Xuan TD, Chung IM. 2007. Rice allelopathy and the possibility for weed management. Annals Applied Biology. 151(3): 325-339. https:// doi.org/10.1111/j.1744-7348.2007.00183.x

Krisnandika AAK, Widajati E, Nawangsih AA. 2017. Pemanfaatan bakteri Pseudomonas Flourescens Rh4003 dan asam askorbat untuk mempertahankan viabilitas benih padi hibrida. Buletin Agrohorti. 5(2): 205-212. https:// doi.org/10.29244/agrob.v5i2.16800

Ma Y, Zhang M, Li Y, Shui J, Zhou Y. 2014. Allelopathy of rice (Oryza sativa L.) root exudates and its relations with Orobanche Cumana Wallr. And Orobanche minor Sm. germination. Journal of Plant Interactions. 9(1): 722-730. https://doi.org/ 10.1080/17429145.2014.912358

Madauna IS. 2009. Kajian pupuk organik cair lengkap dosis rendah pada sistem budidaya tanpa olah tanah terhadap pertumbuhan gulma dan hasil jagung. Jurnal Agroland. 16(1): 24-32.

Marom N, Rizal F, Bintoro M. 2017. Uji efektivitas saat pemberian dan konsentrasi PGPR (Plant Growth Promoting Rhizobacteria) terhadap produksi dan mutu benih kacang tanah (Arachis hypogaea L.). Agriprima. 1(2): 174-184. https://doi.org/ 10.25047/agriprima.v1i2.43

Nafiah VI, Suryanto A. 2018. Study of PGPR (Plant Growth Promoting Rhizobacteria) at different level of nitrogen application upland rice (Oryza sativa L.). Jurnal Produksi Tanaman. 6(7): 1588-1596. 
Nasib SB, Suketi K., Widodo WD. 2016. Pengaruh Plant Growth Promoting Rhizobacteria terhadap bibit dan pertumbuhan awal pepaya. Buletin Agrohorti. 4(1): 63-69. https://doi.org/ 10.29244/agrob.v4i1.15002

Nasrun, Nurmansah. 2016. Keefektifan Formula Pseudomonas fluorescens untuk mengendalikan penyakit layu bakteri dan meningkatkan pertumbuhan tanaman nilam. Jurnal Fitopatologi Indonesia. 12(2): 46-52. https:/ /doi.org/10.14692/jifi.12.2.46

Navitasari L, Soesanto L, Ahadiyat YR. 2013. Pengaruh aplikasi Pseudomonas fluorescens P60 terhadap mutu patologis, mutu fisiologis, dan pertumbuhan bibit padi IR 64. Jurnal Hama dan Penyakit Tumbuhan Tropika. 13(2): 179-190. https://doi.org/10.23960/j.hptt.213179-190

Rahnavard A, Ashrafi ZY, Alizade HM, Sadeghi S. 2009. Studies on the effect of fertilizer application and crop rotation on the weed infested fields in Iran. Journal of Agricultural Technology. 5(1): 41-50.

Rakian TC, Karimuna L, Taufik M, Sutariati GAK, Muhidin, Fermin U. 2018. The effectiveness of various Rhizobacteria carriers to improve the shelf life and the stability of Rhizobacteria as Bioherbicide. IOP Conference Series Earth Environmental Science. 122, 012032. https:// doi.org/10.1088/1755-1315/122/1/012032

Seal A, Pratley JE. 2010. The specificity of allelopathy in rice (Oryza sativa). Weed Research. 50: 303-311. https://doi.org/10.1111/j.1365-3180. 2010.00783.x

Sennang NR, Syam'un E, Dachlan A. 2012. Pertumbuhan dan produksi padi yang diaplikasi pupuk organik dan pupuk hayati. Jurnal Agrovigor. 11(2): 61-170.

Setiawati MR, Sofyan ET, Mutaqin Z. 2016. Pengaruh pupuk hayati padat terhadap serapan $n$ dan $p$ tanaman, komponen hasil dan hasil padi sawah (Oryza sativa L.). Jurnal Agroekoteknologi. 8(2): 120-130.

Soil Survey Staff. 2014. Keys to soil taxonomy. $12^{\text {th }}$ eds. Natural Resources Concervation Service. United State Department of Agriculture. Washington. USA.

Sulistyoningtyas ME, Roviq M, Wardiyati T. 2017. Pengaruh pemberian PGPR (Plant Growth
Promoting Rhizobacteria) pada pertumbuhan bud chip tebu (Saccharum officinarum L.). Jurnal Produksi Tanaman. 5(3): 396-403.

Supartha INY, Wijana G, Adnyana GM. 2012. Aplikasi jenis pupuk organik pada tanaman padi sistem pertanian organik. E-Jurnal Agroteknologi Tropika. 1(2): 98-106.

Supriyo A, Minarsih S, Prayudi B. 2014. Efektifitas pemberian pupuk hayati terhadap pertumbuhan dan hasil padi gogo pada tanah kering. Agritech. 16(1): $1-12$.

Suryadiyansyah. 2017. Peran bioseed treatment dan pupuk hayati terhadap pertumbuhan dan produksi tanaman padi serta dinamika investasi gulma pada tanaman padi sawah. [Skripsi]. Bogor (ID): Institut Pertanian Bogor.

Tang L, Wan K, Cheng C, Li R, Wang D, Pan J, Tao Y, Xie J, Chen F. 2014. Effect of fertilization patterns on the assemblage of weed communities in an upland winter wheat field. Journal of Plant Ecology. 7(1): 39-50. https://doi.org/10.1093/jpe/rtt018

Taufik, M. 2010. Pertumbuhan dan produksi tanaman cabai yang diaplikasi plant growth promoting rhizobakteria. Jurnal Agrivigor. 10(1): 99-107.

Touré A, Sogbedji JM, Gumedzoé YMD. 2013. The critical period of weed interference in upland rice in northern Guinea savanna: Field measurement and model prediction. African Journal of Agricultural Research. 8(17): 1748-1759. https:// doi.org/10.5897/AJAR12.1688

Triyono A, Purwanto, Budiyono. 2013. Efisiensi penggunaan pupuk- $\mathrm{N}$ untuk pengurangan kehilangan nitrat pada lahan pertanian. In: Prosiding Seminar Nasional Pengelolaan Sumber Daya Alam dan Lingkungan. Universitas Dipenogoro, Semarang, 27 Agustus 2013. Semarang (ID).

Utami AP, Agustiyani D, Handayanto E. 2018. Pengaruh PGPR (Plant Growth Promoting Rhizobacteria), kapur, dan kompos pada tanaman kedelai di ultisol Cibinong, Bogor. Jurnal Tanah dan Sumberdaya Lahan. 5(1): 629-635.

Utami S, Purdyaningrum LR. 2012. Struktur komunitas gulma padi (Oryza sativa L.) sawah organik dan sawah sintetik di Desa Ketapang, Kec. Susukan, Kab. Semarang. Bioma. 14(2): 91-95. https:// doi.org/10.14710/bioma.14.2.91-95 